\title{
A COMPARATIVE ANALYSIS OF VISUAL AGENDA-SETTING IN REPORTING ISLAM
}

\author{
Isyaku Hassan ${ }^{1+}$ \\ Mohd Nazri Latiff \\ Azmi $^{2}$
}

\author{
${ }_{1,2}^{1, F a c u l t y}$ of Languages and Communication, Universiti Sultan Zainal \\ Abidin, Terengganu, Malaysia
}

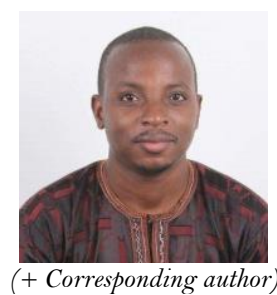

Wh Check for updates

\section{Article History}

Received: 25 May 2018 Revised: 20 June 2018 Accepted: 2 July 2018

Published: 9 July 2018

Keywords

Visual bias

News reporting

Islam

Terrorism.

\begin{abstract}
The media set the agenda of public discourse and define people's perception of the issues. Research shows that analysis of visual elements in the media coverage of Islam is under-represented. This study explores and compares visual agenda-setting of Islam in selected Nigerian and Malaysian newspapers. Punch and Vanguard were chosen from Nigeria while The Star and New Straits Times were chosen from Malaysia based on their online readership. The study focused on content analysis of 425 photos and 23 videos used in the selected newspapers. Sample was collected from November 2015 until September 2016. Only photos and videos used in articles directly related to Islam were collected from the respective websites of the newspapers. It was found that Nigerian newspapers used more violent photos in reporting Islam than Malaysian newspapers. Of all the photos used in the selected newspapers, 43 reflected violence blamed on Islam while 382 were non-violent. None of the videos reflected violence. Though the use of violent photos is minimal in the newspapers, their implication might be highly influential. Visual bias could be avoided through collective effort of journalists, editors, and corporate ownership of the media.
\end{abstract}

Contribution/ Originality: This study contributes in providing a better understanding of how Islam is visually represented in the media by analyzing visuals in Islam-related news stories, particularly in Muslim majority nations.

\section{INTRODUCTION}

Controversies dominate the media coverage of religion, and Islam has become the main focus of the media in recent years. Newspapers tend to focus on Islam as a backward religion (Mohamed et al., 2017). It should be noted that stereotyped depiction of Islam in the media is not a new phenomenon. Thompson (2013) pointed out that Islam has been subject to certain trends of depictions that are as old as the news media themselves. An opinionated part of the media content contributes to the depiction Islam as a religion of violence. Islam is labeled as being extremely different from the western beliefs. Ali et al. (2009) claimed that conventional media in Europe and the US have for long been propagating false information and highlighting negative issues about Islam. As a result of the misleading images, which are mostly created and manipulated by the media, Islam is the name of negativity in the West. It is 
commonly believed that the western media repeatedly misrepresent and inaccurately interpret Islam and its manifestation.

News media content depicts negative images of Islam and Muslims. Mostly, the newspapers give priority to issues that highlight the immoral activities of Muslims compared to the moral ones. The existence of active terrorist groups in Muslim countries also affects the Islam-related news content in such countries (Abu et al., 2017). According to Rupar (2012) the unfortunate instances of media reportage of Islam typically involve negative labeling, designated use of figures, generalizing events, portraying one side of story, using pejorative words, combining truths and opinions, lack of fact proving, and miss-matching of headlines, news content, imageries and sound. Newspapers use a combination of words and visuals to report news stories. They provide audiences with visual messages, which could be influential (Barrett and Barrington, 2005).

It can be argued that the media contribute to the society's ignorance about Islam. Ramji (2016) argued that the media failed to demonstrate how Muslims across the globe could recognize their own destiny and beliefs in the new global order. This indicates the media's inability to provide public with the true picture of Islam. This argument lies in the particular ways of reporting the stories. According to Thussu (2011) ignorance about Islam results in the failure to identify the role of Islam in developing the modern society and offers possibility for anti-Islamic propaganda. The media set the agenda of public discourse and define people's perception of the issues. Research shows that analysis of visual elements in the media coverage of Islam is under-represented. Also, Muslim nations and non-western media have been mostly neglected (Ahmed and Matthes, 2017). Therefore, this study explores and compares visual agenda-setting of Islam in selected Nigerian and Malaysian newspapers. This study contributes in providing a better understanding of how Islam is visually represented in the media by analyzing visuals in Islamrelated news stories, particularly in Muslim-majority nations. Since studies on the relationship between media and Islam focused on the western society, it could be interesting to see how the media in Muslim-majority nations report Islam.

\section{VISUAL AGENDA-SETTING IN REPORTING ISLAM}

Continuous criticism on the way visuals are used in the media is predominant in communication literature. The use of explicitly violent images of terrorism, disasters, accidents, or executions is identified as an increasing occurrence and receiving negative criticism. For instance, photographs are taken out of the context which gives them meaning in their original use. Photos and videos are usually edited to suit new purposes for which they were not originally intended. According to Jacobsen et al. (2012) stereotypes were mostly reproduced in the graphic representations of the articles, for example by displaying individuals praying, 'ghetto areas', Muslim women wearing burkas, or Muslims with extended beards wearing traditional Islamic attire. Negative photos in news reports mostly focus on violence, which represent beheading stoning, mugshot and flogging. Readers are always bombarded with scenes of violence in the media (Moore et al., 2008; Engelhard et al., 2011).

The findings of Moore et al. (2008) revealed that images used in newspapers usually explain the prevalence of mugshots, which are encoded with numerous negative connotations. The images depict terrorist suspects or 'extremist' figures. The most popular locations for photographs of British Muslims are outside a police station or a law court. There was high proportion of images of people protesting or demonstrating. The authors argued that the widespread use of mugshots and images of Muslims outside police stations and law courts is very much in keeping with the high proportion of terrorism related stories about British Muslims.

Some studies, such as the one conducted by Eltantawy (2007) exemplified how the media depict Muslims negatively in photos. According to the study, most of the photos that accompany news stories involving Muslims are irrelevant to the reported news. The author stated that examples of the western news stories and images are common today. People are now familiar with images of Arab and Muslim women. For instance, the Afghani burqa, 
worn by women, is now famous, following the many US media reports and images during the war on Afghanistan in 2001 .

Also, one of the common pictures disseminated by the US media of Iraq's January 2005 elections was that of Iraqi woman wearing a black headscarf, showing off her ink-stained fingers after casting her vote. During presidential elections of Iran in June 2005, the US media coverage included pictures of Iranian women, attired in black Abayas from head to toe. In the same vein, during presidential elections of Egypt in September, 2005; the media bombarded audience with images of women in various colored headscarves. The aforementioned examples indicate the media's attention on negative portrayal of Muslims using images of the veil or headscarf. The news stories accompanying these images are inconsistent with the images. Muslims are portrayed as 'Other' and at times completely mysterious or backward.

In addition, there is much confusion created by the media through the use of photos to draw people's attention to issues such as those related to niqab, burqa and hijab. In broadcast media, the situation is intensified by the fact that in countries like France there are very few women who wear the integral veil, and the images of a minority of women wearing the veil are exaggerated to emphasize the difference. In fact, treatment of these issues in the media reveals the way in which politicians treat the issue in the Veil Commission. It is caricatured, mocked, and the coverage has a detrimental outcome, which is precisely contrary to what many journalists would have anticipated (Rupar, 2012). Attention should be given to the use of photos in the media as they have significant influence on audience's perception of news reports either in print or broadcast media.

Akbarzadeh and Smith (2005) argued that Muslims as a community of faith are not 'a race' because they belong to no single culture. Although not all Arabs are Muslim, but dominant and frequent images of Islam come from the Middle East. These images are representations of men in white attires with long beards and machine guns and uneducated women laced in hijabs and burkas. This indicates that the media ignores the diversity of Islamic practices. Eltantawy (2007) noted that more attention should be given to visual images because they provide more contexts regarding the depiction of Muslims in the news when combined with the print stories. Images have more influence on audience's perception compared to the written words which can only be accessed by a literate audience.

Images are usually part of the features and tone of newspaper articles. Barrett and Barrington (2005) asserted that most studies concerned with the media's impact on people's attitude focused on text and verbal messages, but beyond these text and verbal messages, the media also provide news consumers with visual images, which can be influential. In addition, Wang (2003) asserted much bias is found in visuals. Therefore, it is imperative to include visuals as variables in newspaper content analysis. Moore et al. (2008) also found that photos are mostly used to accompany newspaper articles.

\subsection{Theoretical Approach}

This study employed Agenda-setting theory to analyze visual representation of Islam in newspapers. McCombs and Shaw (1972) provided the first strong experimental support of agenda-setting effect in their study of the 1968 presidential campaign. Their analysis revealed that when the media report certain issues more saliently than others, those salient issues became the focus of the campaign (Potter, 2012). The basic assumption of this theory is that the media create a particular image of reality whether consciously or unconsciously, and then confront the audience on a daily basis with issues that are important according to the media. The media then release a list of topics similar to the agenda of meeting. As a result of omission of certain issues and emphasis on others, a particular way for the audience to think about reality is established (Fourie, 2001).

The findings of McCombs and Shaw (1972) indicated a significant relationship between the media and public agenda. Agenda-setting theory is still developing both in focus and in dimension. McCombs and his associates proposed the most recent development in which they focused on a new level referred to as "second level of agendasetting”. This model views agenda as an abstract notion. In this regard, it is assumed that many other things beside 
issues could be items on the list. Agenda-setting theory is credited to McCombs and Shaw (1972) who conducted the first systematic study of the agenda-setting hypothesis. The power of media to set society's agenda by focusing on public attention on particular issues is a well-documented phenomenon. Agenda-setting depends on the ability of the media to provide salience to a topic while de-emphasizing others in the process of communication (Okwuchukwu, 2014).

To identify salience in media agenda-setting, studies have focused on its attention level (Lim, 2010). Understanding the wider world has been attributed to effective use of information disseminated through the media. Agenda-setting theory presumes that what the media consider important will ultimately be reflected by what the society will come to think are important. The theory enables the construction of societal beliefs and the dissemination of values and devalues of a particular topic. Focus of people's attention is shifted away from immediate effects on attitudes and opinions to long term effects on cognitions. Newspapers offer cues about the salience of issues in the daily news, such as in lead story on page one, other front page displays, and large headlines. By repeating these cues constantly, the newspapers effectively communicate the importance of each issue. According to Folarin (1998) there are four elements associated with agenda-setting - the extent or frequency of reporting, the degree of conflict generated by the reports, the level of prominence attributed to the issue, and the collective media-specific effect over time. The ability of the media to raise the importance of an issue in the public's mind depends on these elements.

\section{METHOD}

This study employed qualitative approach in which content analysis was used to collect and analyze data. Many current studies use qualitative content analysis (Zhang and Wildemuth, 2009). This study corroborated evidences from content analysis to support the theme. Using this method, the study explores and compares visual agendasetting of Islam in selected Nigerian and Malaysian newspapers. According to Dart and Allen (2000) one way to analyze charges of unfairness and preconceived notion in news reporting is to compare the approaches of various news media to the phenomenon under investigation. Content analysis allows for the comparison of possible agenda setters' bias of the events (Cissel, 2012). As a research technique, content analysis enables communication researchers to make inferences about the influences of news on the audience. Content analysis centers on media message characteristics and can provide specific media content that can be categorically analyzed to produce results and provide useful information.

Nigerian and Malaysian newspapers were selected simply on the basis of both sharing similarities from religious and media perspective in many ways. Both newspapers can be historically traced to the colonial era under the same colonial masters. Nigeria and Malaysia are Muslim-majority nations, having had earlier contact with Islam (Ridgeon, 2013; Saidu, 2014). Since visual and online news analysis is infrequent in Muslim nations, it would be interesting to see how the selected newspapers use visuals in reporting Islam.

Images are usually part of the features and tone of newspaper articles. Therefore, data was collected from relevant articles in the selected newspapers using purposive sampling method. Purposive sampling refers to a form of non-probability sampling in which decisions concerning the elements to be included in the sample are taken by the researcher (Palys, 2008). Two different divisions of sampling procedures were used: Sampling for the newspapers and sampling for related articles in the newspapers. Four national newspapers with highest readership were selected for analysis. Two newspapers form each country were chosen for comparison purpose. Punch and Vanguard were chosen from Nigeria while The Star and New Straits Times were chosen from Malaysia. Sample was collected from November 2015 until September 2016.

The researcher conducted an internet-based search for newspaper articles on Islam. The aim was to locate the news articles relating to Islam in the selected newspapers. The articles were accessed from the respective digital archives of the newspapers. Islam and Muslims were used as words. All news articles containing visuals were 
included in the content analysis. Any article that focusses upon report about Islam or Muslims fulfills the inclusion criteria. Only articles that touch on issues directly related to Islam were selected. The content of each article in the original sample was read and scrutinized for relevance. Only straight news and feature news stories were chosen for analysis. The units of content analysis in the present study are news articles - straight news and feature stories from the selected newspapers.

The present study considered photos and videos used for Islam-related news in the selected newspapers were analyzed. Coding characteristics included Islam-related photos and videos used in the selected newspapers. The use of visuals to profile Islam-related events in the news articles is categorized into violent photos/videos, non-violent photos/videos. The data coded using hierarchical code system. The advantage of hierarchical coding is the amount of information it can represent in a relatively small number of digits (Hsieh and Shannon, 2005). To assess the level of agreement between ratings on the article coding, Cohen's kappa test was used. Cohen's kappa coefficient is a statistic which measures inter-rater agreement between two raters for categorical items. Cross-tabulation was used to comparatively analyze the photos and videos used in reporting Islam. It is a joint frequency distribution of cases based on two or more categorical variables (Michael, 2001).

\section{FINDINGS}

The context and circumstance of the use of photos and videos were studied through their relationship with the texts in reporting Islam, and Islam-related terms. Only Islam-related articles published with visuals in the selected newspapers between November 2015 and September 2016 were analyzed. The newspapers produced 425 photos and 23 videos within the aforementioned period. Nigerian newspapers, Punch and Vanguard, produced 173 photos while Malaysian newspapers, The Star and New Straight Times, produced 252 photos and 23 videos. This clearly indicates that Malaysian newspapers produced more Islam-related articles with visuals within the chosen period of data collection. The following table depicts the photos and videos accompanying Islam-related articles in the selected newspapers.

Table-1. Use of photos/videos in Islam-related articles

\begin{tabular}{l|l|l|l|l|l}
\hline \multirow{2}{*}{ Use of photo } & Nigerian newspapers & \multicolumn{2}{l}{ Malaysian newspapers } & Total \\
\cline { 2 - 6 } & $\mathbf{N}$ & $\mathbf{0}$ & $\mathbf{N}$ & $\mathbf{\%}$ & $\mathbf{N}$ \\
\hline Violent photo & 19 & 10.1 & 24 & 9.52 & 43 \\
\hline Non-violent photo & 154 & 89.0 & 228 & 90.48 & 382 \\
\hline Violent video & 0 & 0.0 & 3 & 13.04 & 3 \\
\hline Non-violent video & 0 & 0.0 & 20 & 86.96 & 20 \\
\hline
\end{tabular}

As depicted in Table 1, Nigerian newspapers used more (10.1\%) violent photos in reporting Islam-related events than Malaysian newspapers, which used 8.7\%. Therefore, it is justifiable that Malaysian newspapers used more $(90.48 \%)$ non-violent photos than Nigerian newspapers, which used $89.0 \%$. Only Malaysian newspapers used violent (13.04) and non-violent (86.96\%) videos respectively. Nigerian newspapers did not use either violent or nonviolent video at all. Of all the photos used in the selected newspapers, 43 reflected violence blamed on Islam while 382 were non-violent. None of the videos reflected violence. There were instances where the same violent photos were used in different Islam-related news reports. It is evident that while Nigerian newspapers used more violent photos, Malaysian newspapers used more non-violent photos in Islam-related news articles. Also, while Malaysian newspapers used both violent and non-violent videos Nigerian newspapers did not use either violent or non-violent video at all.

Usually, it has been a ploy for media organizations to attract more and more readers or viewers by using violent photos in covering various events for shock appeal. Though the use of violent photos is minimal in the selected newspapers, their implication might be highly influential. However, scholars argue whether Islam-related 
violent photos used on the pages of newspapers are meant to attack Islam as evinced by the tone of the articles. Constant use of violent photos might be eerie or even eerier to people's perception about the subject being discussed or reported. As such, the audience's minds could be inclined to negative portrayal of, and amass negative perception of Islam. Cunningham (1992) asserted that the use of explicitly violent images of terrorism and other incidents occurs frequently. In the same vein, Putnis (1994) argued that photos are taken out of context and edited to suit new purposes for which they were not originally intended. Repetitious use of violent photos might gradually convince readers who are ignorant of Islam to believe that what they view represent Islam.

\section{DISCUSSION}

This study focused on the use of visuals to draw the reader's attention, which is currently prevalent in most newspapers. A situation whereby the visuals are presented to evoke specific responses or prejudice the reader to view the news one way is referred to as 'visual biases'. In this study, $19.62 \%$ of all the photos accompanying Islamrelated articles in the selected newspapers reflected violence blamed on Islam. There were instances where the same violent photos were used in different news articles. In this case, the photo selection accuracy in the selected newspapers might be questioned. According to Barrett and Barrington (2005) newspaper photo selection process is mostly biased, either intentional or unintentional. This is in line with the assertion made by Engelhard et al. (2011) that newspaper audiences are continuously bombarded with violent scenes in the media. The question here is why the same photos are repeated in several instances. In this regard, Moore et al. (2008) asserted that irrelevant images encoded with numerous negative connotations are used in newspapers to sensationalize events.

There have been conscious or unconscious distortions of facts committed by the newspapers in relation to the use of photos in reporting Islam. For example, on June 13, 2016, Punch newspaper splashed a large photograph beneath a story headlined "DSS invites Osun religious leaders over hijab crisis". Surprisingly, a group of armed militia appeared in the photo. In another scenario, Vanguard newspaper published a story on July 26, 2016 headlined "Appeal court lifts ban on hijab in Lagos public schools" which was accompanied by a photo of infuriated hijabed women". The photo was a duplication of the one that has already been used on June 10, 2016 to report a different event under the headline "Hijab crisis: Osun CAN orders Christian students to attend classes in church robes". It should be noted that this kind of media product is produced for the consumption of heterogeneous audiences.

It was found that Nigerian newspapers used more violent photos in reporting Islam than Malaysian newspapers. This is undeniably logical, since the Nigeria battles with domestic terrorism and ethno-religious crisis. The findings reported by Chibundu and Ishak (2014) suggested that Nigeria is more prone to crisis than Malaysia. Some studies (Eltantawy, 2007; Jacobsen et al., 2012) also found that photos and videos are commonly used to cover violent acts and are taken out of context which gives them meaning in their original use. Visuals are usually edited to suit different purposes for which they were not initially intended. It has typically been a strategy of the media outlets to use photos or videos in sensationalizing their news in order to catch the audience's attention.

Considering the assumption of Agenda-setting theory, repetitious use of violent photos might be influential on people's perception of Islam, and people - especially those who are ignorant of Islam - might begin to accept as true that what they view suggestively represent Islam. This is likely to occur whether the photos are intentionally or unintentionally meant to attack Islam, as evinced by the tone of the articles. In this situation, the manipulative capacity of the media messages, coupled with the audience's individual frames, develops into prejudices and amass negative perception of Islam. In fact, the explicitly violent photos used in reporting Islam, though insignificant in number, are capable of generating inordinate consequences, especially when used out of context (Eltantawy, 2007).

The findings reported in this study show that Malaysia is more sensitive to media control on religious issues than Nigeria. The Malaysian government's warning under Prime Minister Dato' Sri Haji Mohammad Najib bin Tun Haji Abdul Razak to suspend The Star newspaper unless it explains a controversial front page that juxtaposed a headline about a terrorist leader with a photo of Muslims praying is an indication of strong media control in 
Malaysia. The Malaysia's interior ministry gave out a "show cause" instruction to the newspaper subsequent to the upheaval it caused on social media. On 27 $7^{\text {th }}$ May 2017, the English daily's front page of the newspaper contained the headline "Malaysian terrorist leader". The headline refers to a citizen of Malaysia as an IS regional leader while a photo of Muslims performing congregational prayer appeared under the headline. The Star stated that it published the photo as part of the annual practice of presenting the first sunset prayers in Ramadan on the newspaper's front page. However, subsequent to the government's instruction, the newspaper's executive editor and its chief editor were suspended (Razak, 2017).

Later, The Star suspended two of its top editors indefinitely, which indicates that the newspaper has taken the responsibility for whatsoever offenses it is perceived or believed to have committed. Spectators stated that the recent incident was different due to its more religious facet. Some of them believed it was normal for the government to interfere in such circumstances. The Star has deeply been criticized for its coverage of terrorism. In 2011, the newspaper suffered from the wrath of the government by running an advertisement in complement for Ramadan and was given a warning. According to Agenda Setting theory, the news media have a great influence on their audiences. Media houses and journalists have the great capability to dictate news stories that are considered newsworthy and how much prominence and space they are assigned.

Based on the assumption of Agenda-setting theory, this study provided evidence on the implication of using visuals to evoke audience's specific prejudices against Islam. Nigerian newspapers used more violent photos in reporting Islam than Malaysian newspapers. Though the use of violent photos in the selected newspapers tends to be minimal, these kinds of photos might generate inordinate consequences. These negative visuals are highly consequential, and if this continuous, Muslims are likely to become victims of the media journalistic content instead of benefiting from the public enlightenment that supposed to be awakening people to the true nature of reality. The findings indicate that Malaysia is more sensitive to media control on religious issues than Nigeria. It should be noted that newspapers in Nigeria are mostly owned by private individuals and groups, unlike Malaysian newspapers which are mainly dominated by the government with strong self-censorship and restrictive regulation (Thomas, 2014).

\section{CONCLUSION}

This study investigated visual agenda-setting of Islam in selected Nigerian and Malaysian newspapers. It is evident from the findings of this study that very few photos and videos used for reporting Islam in the selected newspapers reflected violence blamed on Islam. However, the implications of these violent photos and videos might be highly influential. The disheartening issue is that most of these negative photos are either irrelevant or used repeatedly in different occasions. Misleading visual representation might influence the way readers perceive Islam. Though the negative visual representation of Islam in the newspapers might be unconscious, it has been proven that not only newspapers in Muslim-minority nations portray negative image of Islam. There is an indication that Malaysia has more effective media control and gate-keeping compared to Nigeria. This is because any information that undergoes rigorous editing and gate-keeping process should, to a great extent, be less biased and manipulated. The possible implications of negative report are significant considering the typical nature of the Agenda-setting theory.

The study offered valuable information regarding the visual agenda-setting in reporting Islam. It provided insights into how newspapers in Muslim-majority nations such as Nigeria and Malaysia photos and videos in reporting Islam. Newspapers have great influence on the society due to the continuous perception that whatever is seen in the media must be the gospel truth. In this study, it is unfortunate that the news reporting of Islam has been called to questions in relation to visual representation. Negative visual representation results in acrimony and antagonism. In the present day, objective, fair, and balanced reporting has been sacrificed in favor of personal or group interest. The influence of visuals should not be overlooked because visual representation becomes part of 
media agenda-setting. Visual bias could be avoided through collective effort of journalists, editors, and corporate ownership of the media.

Funding: This study received no specific financial support.

Competing Interests: The authors declare that they have no competing interests.

Contributors/Acknowledgement: Both authors contributed equally to the conception and design of the study.

\section{REFERENCES}

Abu, B.S.Z., K.A. Muhammed and K. Yusoff, 2017. The similarity of radical Islamic ideology between the Malaysian groups of Jemaah Islamiyah, Kumpulan Militan Malaysia and Islamic State (Daesh). Journal of Nusantara Studies, 2(2): 155-168. View at Google Scholar

Ahmed, S. and J. Matthes, 2017. Media representation of muslims and islam from 2000 to 2015: A meta-analysis. International Communication Gazette, 79(3): 219-244. View at Google Scholar | View at Publisher

Akbarzadeh, S. and B. Smith, 2005. The representation of Islam and muslims in the media (The Age and Herald Sun Newspapers). Monash, Australia: Monash University Press.

Ali, S., M. Khalid and M.I. Lodhi, 2009. Negative image of Islam and US mass media: How to improve the image of islam and muslim countries. Social Sciences and Humanities, 25(2): 43-49. View at Google Scholar

Barrett, A.W. and L.W. Barrington, 2005. Bias in newspaper photograph selection. Political Research Quarterly, 58(4): 609-618. View at Google Scholar | View at Publisher

Chibundu, I.S. and M.S.A. Ishak, 2014. A comparative analysis of crisis reporting in the Malaysian and Nigerian newspapers. GSTF Journal on Media \& Communications, 1(1): 80-89.

Cissel, M., 2012. Media framing: A comparative content analysis on mainstream and alternative news coverage of occupy wall street. Elon Journal of Undergraduate Research in Communications, 3(1): 67-77. View at Google Scholar

Cunningham, S., 1992. Framing culture: Criticism and policy in Australia. Sydney: Allen \& Unwin.

Dart, J. and J.R. Allen, 2000. Bridging the gap: Religion and the news media. Washington, DC: Forum First Amendment Center.

Eltantawy, N.M.A., 2007. US newspaper representation of muslim and Arab women Post 9/11. (Doctoral Dissertation). Georgia State University, USA.

Engelhard, C.R., B.D. Bartholow, G.T. Kerr and B.J. Bushman, 2011. This is your brain on violent video games: Neural desensitization to violence predicts increased aggression following violent video game exposure. Journal of Experimental Social Psychology, 47(5): 1033-1036. View at Google Scholar | View at Publisher

Folarin, B., 1998. Theories of mass communication: An introductory text. Ibadan: Stirling Horder Publishers (Nig.) Ltd.

Fourie, P.J., 2001. Media studies: Institutions, theories, and issues. Claremont: Jutaand Company Ltd.

Hsieh, H.F. and S.E. Shannon, 2005. Three approaches to qualitative content analysis. Qualitative Health Research, 15(9): 12771288. View at Google Scholar | View at Publisher

Jacobsen, S.J., T.G. Jensen, K. Vitus and K. Weibel, 2012. Analysis of Danish media setting and framing of muslims, islam and racism.

Retrieved

from

http://www.ces.uc.pt/projectos/tolerace/media/Working\%20paper\%205/Analysis\%20of\%20Danish\%20Media\%20set ting\%20and\%20framing\%20of\%20Muslims\%20Islam\%20and\%20racism.pdf.

Lim, J., 2010. Convergence of attention and prominence dimensions of salience among major online newspapers. Journal of Computer-Mediated Communication, 15(2): 293-313. View at Google Scholar | View at Publisher

McCombs, M. and D. Shaw, 1972. The agenda-setting function of mass media. Public Opinion Quarterly, 36(2): 176-187. View at Google Scholar | View at Publisher

Michael, R.S., 2001. Crosstabulation \& chi square. Bloomington: Indiana University. 
Mohamed, A., R.A. Rashid, Y. Kamariah, S.B.A. Rahman, S. Darus, R. Musa and K.S. Mat Teh, 2017. Discourse analysis on newspaper reports of apostasy cases. Journal for the Study of Religions and Ideologies, 16(48): 96-111. View at Google Scholar

Moore, K., P. Mason and J.M.W. Lewis, 2008. Images of Islam in the UK: The representation of British muslims in the national print news media 2000-2008. Retrieved from http://orca.cf.ac.uk/id/eprint/18277.

Okwuchukwu, O.G., 2014. The influence of media ownership and control on media agenda setting in Nigeria. International Journal of Humanities Social Sciences and Education, 7(1): 36-45. View at Google Scholar

Palys, T., 2008. Purposive sampling. In L. M.Given (Ed.). The Sage encyclopedia of qualitative research methods. Los Angeles: SAGE Publications, 2: 697-8.

Potter, J.W., 2012. Media effects. California: SAGE Publication Limited.

Putnis, P., 1994. Displaced, re-cut and recycled: File tape in television news. Gold Coast: Centre for Journalism Research and Education.

Ramji, R., 2016. From navy seals to the siege: Getting to know the muslim terrorist, hollywood style. Journal of Religion \& Film, 9(2): 61-72. View at Google Scholar

Razak, R., 2017. Mixing islam and terrorism: A blunder too far for Malaysia's star? Retrieved from http://www.scmp.com/week-asia/politics/article/2096702/mixing-islam-and-terrorism-blunder-too-far-malaysiasstar.

Ridgeon, L., 2013. Islamic interpretations of christianity. Milton Park: Routledge.

Rupar, V., 2012. Gettingthe facts right: Reporting ethnicity and religion. Druk. Hoeilaart, International Federation of Journalists: International Federation of Journals, Brussels.

Saidu, S., 2014. A comparative analysis of production sharing contracts of selected developing countries: Nigeria, Indonesia, Malaysia and equatorial Guinea. Journal of Finance and Accounting, 2(2): 34-40. View at Google Scholar $\mid$ View at Publisher DOI.

Thomas, R.L., 2014. Monopolizing the nation: Soft censorship in Malaysia. World Association of Newspapers and News Publishers (WAN-IFRA). Retrieved from http://www.wan-ifra.org/articles/2014/12/18/monopolizing-the-nationsoft-censorshipmalaysia.

Thompson, P.M., 2013. Allen's Islamophobia and the British news media: A critical evaluation of Islamophobia as a concept and its application to the written news media in Britain between 2001 and 2008. (Master's Thesis). University of Wales, UK.

Thussu, D.K., 2011. How media terrorism manipulates truth. Economic and Political Weekly, 32(6): 264-267. View at Google Scholar

Wang, X., 2003. Media ownership and objectivity. Master's Thesis. Louisiana State University, Baton Rouge.

Zhang, Y. and B.M. Wildemuth, 2009. Qualitative analysis of content. Applications of Social Research Methods to Questions in Information and Library Science, 1(2): 308319. View at Google Scholar | View at Publisher 